\title{
Nitric Oxide Synthase Mediates the Ability of Darbepoetin Alfa to Improve the Cognitive Performance of STOP Null Mice
}

\author{
Kosuke Kajitani $^{1,2}$, Michael Thorne ${ }^{1,2}$, Michel Samson' and George S Robertson ${ }^{*, 1,2}$ \\ 'Department of Psychiatry, Sir Charles Tupper Medical Building, Dalhousie University, Halifax, Nova Scotia, Canada; ${ }^{2}$ Department of \\ Pharmacology, Sir Charles Tupper Medical Building, Dalhousie University, Halifax, Nova Scotia, Canada
}

\begin{abstract}
STOP (stable tubule only polypeptide) null mice display neurochemical and behavioral abnormalities that resemble several well-recognized features of schizophrenia. Recent evidence suggests that the hematopoietic growth factor erythropoietin improves the cognitive performance of schizophrenics. The mechanism, however, by which erythropoietin is able to improve the cognition of schizophrenics is unclear. To address this question, we first determined whether acute administration of the erythropoietin analog known as darbepoetin alfa (D. alfa) improved performance deficits of STOP null mice in the novel objective recognition task (NORT). NORT performance of STOP null mice, but not wild-type littermates, was enhanced $3 \mathrm{~h}$ after a single injection of D. alfa ( $25 \mu \mathrm{g} / \mathrm{kg}$, i.p.). Improved NORT performance was accompanied by elevated NADPH diaphorase staining in the ventral hippocampus as well as medial and cortical aspects of the amygdala, indicative of increased nitric oxide synthase (NOS) activity in these structures. NOS generates the intracellular messenger nitric oxide (NO) implicated in learning and memory. In keeping with this hypothesis, D. alfa significantly increased NO metabolite levels (nitrate and nitrite, NOx) in the hippocampus of both wild-type and STOP null mice. The NOS inhibitor, $N(G)$-nitro-L- arginine methyl ester (L-NAME; $25 \mathrm{mg} / \mathrm{kg}$, i.p.), completely reversed the increase in hippocampal NOx levels produced by D. alfa. Moreover, L-NAME also inhibited the ability of D. alfa to improve the NORT performance of STOP null mice. Taken together, these observations suggest D. alfa enhances the NORT performance of STOP null mice by increasing production of NO. Neuropsychopharmacology (2010) 35, 17I8-1728; doi:I0.1038/npp.2010.36; published online 24 March 2010
\end{abstract}

Keywords: Darbepoetin alfa; schizophrenia; STOP null mouse; novel objective recognition task; nitric oxide; L-NAME

\section{INTRODUCTION}

Schizophrenia is a common psychiatric disorder that affects approximately $1 \%$ of the population worldwide (Mueser and McGurk, 2004; Sawa and Snyder, 2002) and is characterized by positive (hallucinations, delusions, disorganized speech, and disorganized behavior) and negative (affective flattening, alogia, and avolition) symptoms (Andreasen and Flaum, 1991; van Os and Kapur, 2009). In addition to these symptoms, cognitive deficits are becoming increasingly recognized as an important feature of schizophrenia (Breier, 2005; Keefe and Fenton, 2007; Ranganath et al, 2008), however, no therapies are currently available that improve the cognitive performance of these patients.

Although the etiology of schizophrenia is poorly understood, converging evidence from a number of fields supports the view that deficits in neuronal connectivity linked to synaptic alterations is a key contributing factor

*Correspondence: Dr GS Robertson, Departments of Psychiatry and Pharmacology, Sir Charles Tupper Medical Building, Faculty of Medicine, Dalhousie University, 5850 College Street, Halifax, Nova Scotia, Canada B3H IX5, Tel: + | 902494 I528, Fax: + I 902494 1388, E-mail: robertgs@dal.ca

${ }^{2}$ These authors contributed equally to this work

Received 19 January 2010; revised 25 February 2010; accepted 25 February 2010 to this devastating disorder (Harrison, 1999; Mirnics et al, 2000; Robertson et al, 2006). For instance, the protein encoded by a gene (disrupted in schizophrenia 1, DISC1) that is mutated in a familial form of schizophrenia is involved in various interactions between microtubulerelated organelles or proteins suggesting that connectivity deficits in schizophrenia may result from dysfunction of the cytoskeleton (Ayhan et al; Callicott et al, 2005). In keeping with this proposal, Shimizu and coworkers have reported an association between schizophrenia and polymorphisms in the gene-encoding microtubule-associated protein 6 (MAP6) (Shimizu et al, 2006). The Map6 gene product known as STOP (stable tubule only peptide) is a $\mathrm{Ca}^{2+}$-calmodulin regulated microtubule-associated protein present in neurons, oligodendrocytes, and astrocytes (Bosc et al, 2003; Denarier et al, 1998; Galiano et al, 2004). Mice lacking a functional copy of STOP (STOP null) display several synaptic abnormalities that are accompanied by an array of cognitive deficits (Begou et al, 2008; Brun et al, 2005; Eastwood et al, 2007; Powell et al, 2007). STOP null mice display a two-fold reduction in pre-synaptic glutamatergic vesicle density in the CA1 region of the hippocampus, a brain structure implicated in learning and memory (Andrieux et al, 2002). This pre-synaptic vesicular depletion is accompanied by deficits in electrophysiological measures of synaptic plasticity such as LTP, long-term depression and post-tetanic potentiation that may account 
for performance deficits in behavioral tests of learning and memory (Andrieux et al, 2002). STOP null mice also show neurochemical, pharmacological and behavioral profiles indicative of hyperactivity of the mesolimbic dopamine system (Bouvrais-Veret et al, 2008; Brun et al, 2005; Fradley et al, 2005). In STOP null mice, mesolimbic dopaminergic hyperactivity is accompanied by reduced glutamatergic transmission (Brenner et al, 2007), an interrelationship now thought to be a neurochemical hallmark of schizophrenia (Carlsson et al, 2000; Jablensky, 2004). Delotterie et al, (2010) reported that long-term treatment with risperidone, a representative atypical antipsychotic drug, did not improve working memory of STOP null mice assessed with the Y maze. This finding is consistent with the lack or weak effects of antipsychotic drugs on cognitive deficits associated with schizophrenia (Young et al, 2009) suggesting that the STOP null mouse may be a useful model for the identification of therapeutics capable of improving the cognition of schizophrenics. Taken together, these findings indicate that the STOP null mice model several important features of schizophrenia.

Erythropoietin (Epo) is a glycoprotein derived from the kidney whose principal function is to stimulate erythropoiesis by inhibiting the programmed cell death of erythrocyte precursors (Ghezzi and Brines, 2004). Epo also has well-established neuroprotective properties in models of cerebral ischemia (Sadamoto et al, 1998; Sakanaka et al, 1998), neuroinflammation (Brines et al, 2000; Li et al, 2004), neuronal injury (Zhang et al, 2010), and neurotoxininduced cell death (Adembri et al, 2004; Orhan et al, 2004). In addition to these neuroprotective properties, recent studies have shown that Epo enhances cognitive and neural measures of executive function using a verbal fluency task and working memory during functional magnetic resonance imaging in healthy volunteers (Miskowiak et al, 2008a) and improves cognitive function in schizophrenia patients (Ehrenreich et al, 2007). Epo is now being considered as an adjunctive therapy for cognitive dysfunction in psychiatric disorders; however, the mechanism by which Epo improves cognition remains unclear. Based on these findings, we hypothesized that acute administration of darbepoetin alfa (D. alfa), an Epo analog, would improve performance deficits of STOP null mice in the novel object recognition task (NORT). Given that Epo has been shown to increase extracellular concentrations of nitric oxide (NO) (Yamamoto et al, 2004), a chemical messenger implicated in learning and memory (Kendrick et al, 1997; Ota et al, 2008), we also hypothesized that D.alfa would increase NO metabolites in the cortex and hippocampus and modulate nitric oxide synthase (NOS) activity within specific structures in the forebrain. Lastly, we hypothesized that administration of the NOS inhibitor L-NAME would abolish the effects of D.alfa on novel object recognition memory, indicating that the effects of D. alfa on memory performance were mediated through NO signaling.

\section{MATERIALS AND METHODS}

\section{Animals}

Adult male and female BALBc/129 SvPas heterozygous STOP mice were obtained from a colony maintained in
Grenoble, France (Andrieux et al, 2002). Mice were crossed with male and female 129S1/SvImJ mice (Jackson Laboratories, Bar Harbor, ME, USA) to produce litters with increased viability. Heterozygous (BALBc/129 SvPas $\mathrm{x}$ 129 S1/SvImJ) breeding pairs were established that generated litters at an approximate ratio of $25 \%$ wild-type (WT): $50 \%$ heterozygous (Het): $25 \%$ homozygous null for STOP (STOP null). Mice were group housed with ad libitum access to food and water, and maintained on a $12 \mathrm{~h}$ lightdark schedule. The Carleton Animal Care Committee at Dalhousie University approved the experimental procedures described in this article and that were also in accordance with the guidelines detailed by the Canada Council on Animal Care. Each of the four groups used to compare the effects of vehicle $(10 \mathrm{ml} / \mathrm{kg}$, i.p.) and darbepoetin alfa (D. alfa; $25 \mu \mathrm{g} / \mathrm{kg}$, i.p.) on the NORT performance of WT and STOP null mice were composed of 12-16 animals (Figure 1). In the case of the nitrate and nitrite (NOx) tissue
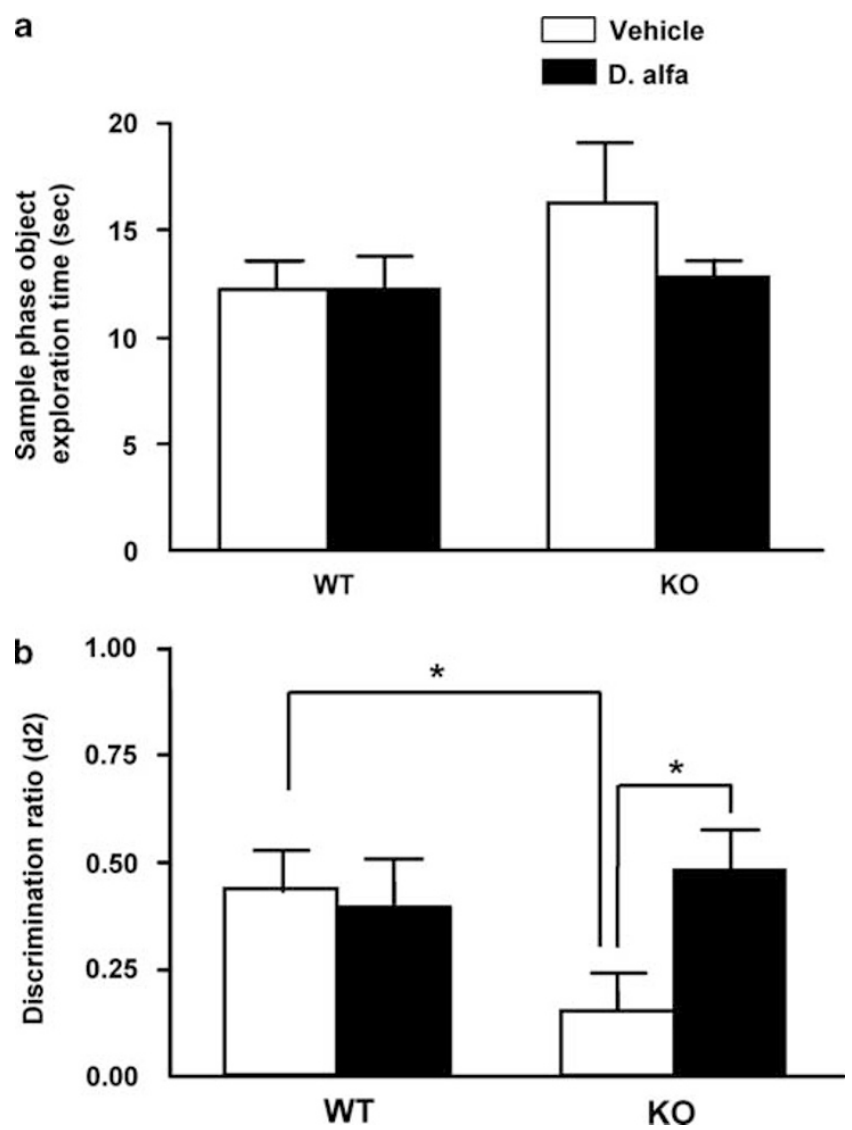

Figure I Acute darbepoetin alfa (D. alfa; $25 \mu \mathrm{g} / \mathrm{kg}$, i.p.) treatment reversed object recognition deficits in STOP null mice. (a) Object exploration time in the sample phase. The time spent exploring objects is shown in the bar graph as mean \pm SEM. Wild-type mice (WT) and STOP null mice (KO) injected with vehicle $(10 \mathrm{ml} / \mathrm{kg}$, i.p.; $W T: N=12, K O$ : $N=13)$ or D. alfa $(25 \mu \mathrm{g} / \mathrm{kg}$, i.p.; $W T: N=12, K O: N=16)$ spent equal amounts of time investigating the objects during the sample phase. (b) Discrimination ratio (d2) in the choice phase is shown in the bar graph as mean \pm SEM. $K O$ mice treated with an acute injection of D. alfa $(25 \mu \mathrm{g} /$ $\mathrm{kg}$ i.p.) displayed a significant improvement in NORT performance compared with vehicle controls. White bars, vehicle $(10 \mathrm{ml} / \mathrm{kg}$, i.p.; WT: $N=12, K O: N=13)$; black bars, D.alfa $(25 \mu g / k g$, i.p.; $W T: ~ N=12, K O:$ $N=16$ ). Two-way ANOVA with Bonferroni post hoc t-test, $* p<0.05$. 
measurements shown in Figure 3, 8-10 animals from each of these four groups were used. For the L-NAME dose-response studies shown in Figure $4 \mathrm{~b}-\mathrm{d}$, each group consisted of 5-6 mice that were also used for NOx tissue measurements (Figure 4a). In the case of the last experiment in which we examined the ability of L-NAME $(25 \mathrm{mg} / \mathrm{kg}$, i.p. $)$ to reverse the effects of D. alfa $(25 \mu \mathrm{g} / \mathrm{kg}$, i.p.) on NORT performance, each group was composed of 8-9 animals (Figure $5 \mathrm{a}$ and $\mathrm{b}$ ). All of these mice in the four groups were used for determination of NOx levels (Figure 5c). For the NADPH diaphorase staining shown in Figure 2, separate groups, composed of 6 mice each, were given vehicle $(10 \mathrm{ml} / \mathrm{kg}$, i.p.) or D. alfa $(25 \mu \mathrm{g} / \mathrm{kg}$, i.p. $)$ and prepared for histological examination of NADPH diaphorase staining.

\section{Drugs}

Darbepoetin alfa (D. alfa: Aranesp, Amgen Therapeutics, Thousand Oaks, CA) was obtained as $100 \mu \mathrm{g} / \mathrm{ml}$ stock and diluted to $2.5 \mu \mathrm{g} / \mathrm{ml}$ in vehicle $(0.1 \%$ bovine serum albumin in $0.1 \mathrm{M}$ phosphate-buffered saline (PBS)) and administered to STOP null mice or WT littermates at a dose of $25 \mu \mathrm{g} / \mathrm{kg}$ (i.p.). Animals received D. alfa or vehicle $(10 \mathrm{ml} / \mathrm{kg}$, i.p.)

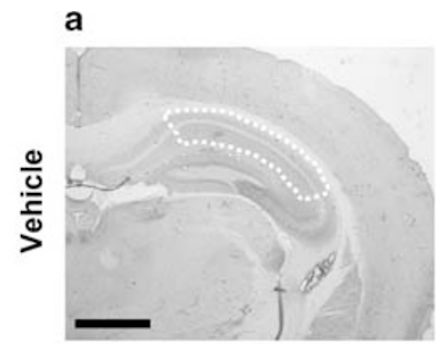

b
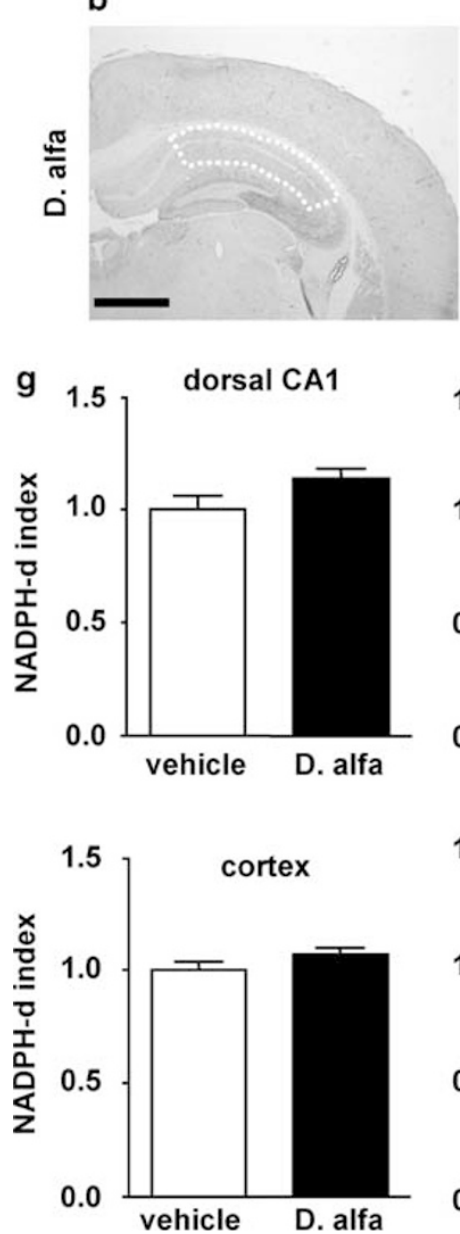

C

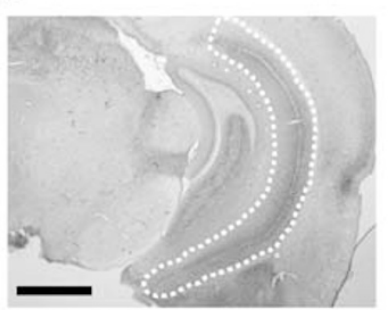

d
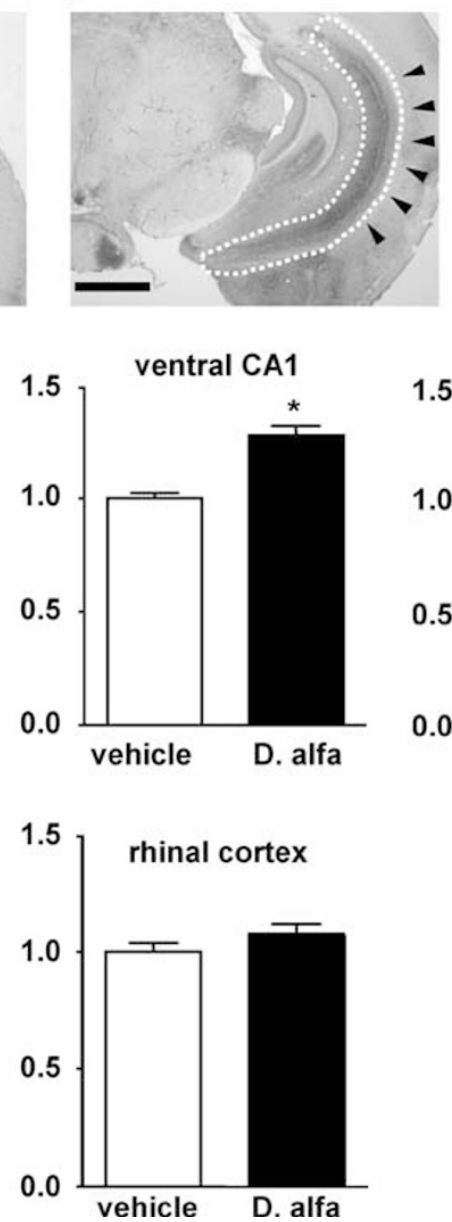

e

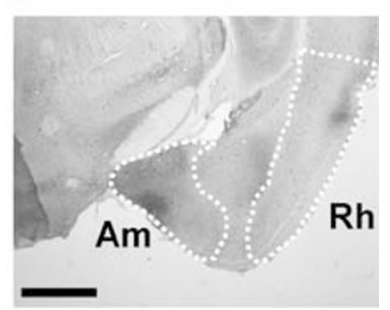

f

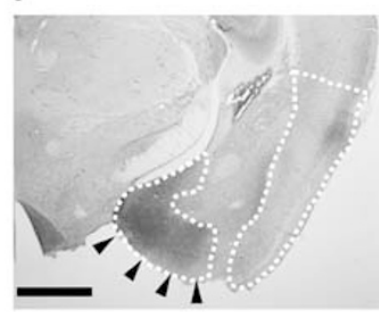

amygdala

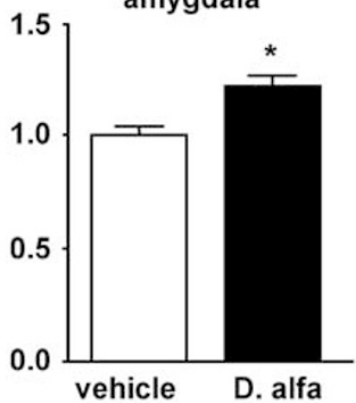

Figure 2 Representative NADPH diaphorase staining in the forebrain of a WT mouse 3-4 h after D. alfa ( $25 \mu \mathrm{gg} / \mathrm{kg}$, i.p.) or vehicle ( I $0 \mathrm{ml} / \mathrm{kg}$, i.p.). (a and b) dorsal hippocampus; Bregma $=-2.30 \mathrm{~mm}$, (c and d) ventral hippocampus; Bregma $=-3.16 \mathrm{~mm}$, (e and f) amygdala (Am) and rhinal cortex (Rh); Bregma $=-2.18 \mathrm{~mm}$. Mice (WT or STOP null) treated with D. alfa $(25 \mu \mathrm{g} / \mathrm{kg}$ i.p.) showed a marked increase in NADPH diaphorase staining in the ventral hippocampus as well as medial and cortical aspects of the amygdala relative to vehicle controls (indicated by arrowheads). Scale bars; I mm. (g) Quantification of signal intensity for NADPH-d staining, bars represent the means \pm SEM of groups composed of six mice each. Mann-Whitney U-test, ${ }^{*} p<0.05$. 
$3 \mathrm{~h}$ before testing. $\mathrm{N}(\mathrm{G})$-nitro-L-arginine methyl ester (L-NAME; Sigma-Aldrich, St Louis, MO, USA) was diluted in sterile water and administered to mice $30 \mathrm{~min}$ before the D. alfa injection at doses of 10,25 , or $50 \mathrm{mg} / \mathrm{kg}$ (i.p.).

\section{Novel Object Recognition Task (NORT)}

NORT is a test of object recognition memory that is dependent upon both the hippocampal formation and the rhinal cortex (Broadbent et al, 2004; Winters et al, 2004). The NORT was performed as described previously (Powell et al, 2007). Briefly, the NORT was conducted in an opaque plexiglass open field $(35 \times 45.5 \times 36 \mathrm{~cm})$. Animals were habituated to the open field in the absence of objects for $5 \mathrm{~min}$ on each of 2 successive days before the test day. On the test day, animals were habituated to the open field for $1 \mathrm{~min}$ and then returned to a holding cage while two identical objects were placed in the open field. During the sample phase, each mouse was placed in the center of the open field oriented towards the objects and the time spent exploring each object was recorded over a 5-min period. The mouse was then returned to the home cage for a delay of $5 \mathrm{~min}$ before being returned to the open field for the choice phase. In the choice phase, the mouse was placed in the center of the open field oriented toward the objects: one familiar object from the sample phase and a novel object. Time spent exploring each object over a 3 -min period was recorded. Exploration was defined as directing the nose toward the object at a distance less than $1 \mathrm{~cm}$, and included placing one or more paws on the object. Sitting beside or on top of the object was not considered exploration. The total time spent investigating both objects in the sample phase was recorded and compared to ensure equal motivation to explore. In the choice phase the proportion of time spent with the novel object was determined by dividing the time spent with the novel object by the total time spent exploring both objects. A discrimination ratio (d2) was calculated by taking the difference between the times spent investigating the novel and familiar objects and dividing that by the time spent investigating both objects during the choice phase. Animals that failed to reach a threshold exploration time in the sample and choice phases (10 and $5 \mathrm{~s}$, respectively) were excluded from the study.

\section{Histology}

Animals were deeply anesthetized with pentobarbital $(30 \mathrm{mg} / \mathrm{kg}$ i.p. $)$ and perfused intracardially with saline followed by cold $4 \%$ paraformaldehyde (PFA) in $0.1 \mathrm{M}$ PBS. The brains were removed, immersed for $12 \mathrm{~h}$ in the same $4 \%$ PFA fixative at $4^{\circ} \mathrm{C}$, and cryoprotected in $30 \%$ sucrose in PBS for $48 \mathrm{~h}$ at $4^{\circ} \mathrm{C}$. The brains were then frozen and stored at $-80^{\circ} \mathrm{C}$ until use. Serial coronal sections ( $30 \mu \mathrm{m}$ thick) were cut on a cryostat, collected as freefloating sections in PBS, and then processed immediately for NADPH diaphorase staining.

\section{NADPH Diaphorase (NADPH-d) Staining}

NADPH-d staining was performed as described previously with some modifications (Hope and Vincent, 1989; Vincent and Kimura, 1992). Sections were rinsed $2 \times 10 \mathrm{~min}$ in
$50 \mathrm{mM}$ Tris-buffer saline (TBS) to equilibrate the tissue, and incubated in NADPH solution ( $1 \mathrm{mM}$ â-NADPH (Sigma-Aldrich) and $0.1 \mathrm{mM}$ Nitrotetrazolium blue (Sigma-Aldrich) in TBS with $0.1 \%$ Tween 20 (TBS-T)) for $70 \mathrm{~min}$ at $37^{\circ} \mathrm{C}$ protected from light. Sections were then rinsed $2 \times 10 \mathrm{~min}$ in TBS-T and stored in TBS-T diluted $1: 1$ with distilled water. Slides were submerged in 100\% xylene and coverslipped using Cytoseal solution (Richard Allan Scientific, Kalamazoo, MI, USA). Slides were viewed using an Axioscope (Carl Zeiss, Toronto, ON, Canada). Brain images were captured with an Axiocam HRc digital camera using imaging software (Canimpex Enterprises, Halifax, NS, Canada).

\section{Measurement of NO Metabolite (Nitrate and Nitrite; NOx) Levels}

For determination of hippocampal and cortical NOx levels, hippocampi and cortices were rapidly dissected from the brains. The dissected hippocampi and cortices were homogenized in $1 \times$ PBS and spun at $10000 \mathrm{~g}$ for $20 \mathrm{~min}$ at $4^{\circ} \mathrm{C}$. The supernatant was placed on $30 \mathrm{kDa}$ filters (Millipore, Etobicoke, ON, Canada) and spun at $14000 \mathrm{~g}$ for $60 \mathrm{~min}$ at $4{ }^{\circ} \mathrm{C}$. The filtrate was collected to measure nitrite levels. The final products of $\mathrm{NO}$ in vivo are nitrite $\left(\mathrm{NO}_{2}^{-}\right)$ and nitrate $\left(\mathrm{NO}_{3}^{-}\right)$. The relative proportions of $\mathrm{NO}_{2}^{-}$and $\mathrm{NO}_{3}^{-}$are variable and cannot be predicted with certainty. Thus the best measure of total NO production is the sum of both $\mathrm{NO}_{2}^{-}$and $\mathrm{NO}_{3}^{-}(\mathrm{NOx})$. This was achieved using a commercial kit from Cayman Chemical (Ann Arbor, MI, USA) that first converts all nitrate to nitrite using nitrate reductase. The second step used a Griess reaction to convert all nitrite into a deep purple azo compound that was detected using a microplate reader. Known concentrations of nitrite were run in tandem to create a standard curve for the quantification of nitrite levels in each homogenate sample derived from the hippocampus. Levels of nitrite were standardized according to protein content to yield $\mu \mathrm{M}$ nitrite/mg protein.

\section{Densitometric Analysis of NADPH-d Staining}

NADPH-d staining was quantified by densitometric analysis performed on every 12 th coronal section ( $30 \mu \mathrm{m}$ thick) taken from the level of the anterior caudate-putamen to the posterior aspect the hippocampus (Bregma $-0.70 \mathrm{~mm}$ to $-3.40 \mathrm{~mm}$ ). All acquired digital images were converted to gray scale and the optical density of using NADPH-d staining measured using ImageJ software (http://rsbweb. nih.gov/ij/). The background grayscale intensity arising from white matter (corpus callosum) was subtracted from that for the regions of interest. Optical density measurements were performed on separate coronal sections for each animal. These values were averaged for each brain region (dorsal hippocampus; five sections (Bregma -1.34 to $-2.46 \mathrm{~mm}$ ), cortex; five sections (Bregma $-1.34 \mathrm{~mm}$ to $-3.40 \mathrm{~mm}$ ), ventral hippocampus; three sections (Bregma -2.46 to $-3.40 \mathrm{~mm}$ ), amygdala; five sections (Bregma -0.70 to $-2.54 \mathrm{~mm}$ ) and rhinal cortex; five sections (Bregma -0.70 to $-2.54 \mathrm{~mm})$ ). For each brain region that was sampled, the average optical density for the vehicle group was first calculated (0-255 gray scale). The optical density 
for NADPH-d staining for each animal was then converted to a NADPH-d index. This was done by dividing the optical density for each animal by the average optical density for the vehicle group. In this way, the average optical density for the vehicle group was defined as $100 \%$ or 1.0 . Optical densities for each member of the D. alfa group were divided by the mean grayscale intensity for the vehicle control group and averaged to yield a mean NADPH-d index for the D. alfa group. Representative images showing the brain regions that were quantified are presented in Figure 2.

\section{Data Analysis}

NADPH-d indices for different treatments were compared using the Mann-Whitney $U$-test (Figure 2). NORT scores and NOx levels were analyzed by two-way analyses of variance (ANOVA) for independent groups as a 2 (genotype: Wild-type, STOP null) $\times 2$ (drug: Vehicle, D. alfa) design followed by Bonferroni post hoc $t$-tests (Figures 1,3 , and 5). For experiments using only WT mice, the results were analyzed using a one-way ANOVA followed by the Newman-Keuls post test to determine differences between individual groups (Figure 4). A level of $p<0.05$ was considered statistically significant.

\section{RESULTS}

\section{Acute Darbepoetin Alfa Treatment Reversed NORT Deficits in STOP Null Mice}

In a first series of experiments, we compared the NORT performance of STOP null and WT mice that received either vehicle $(10 \mathrm{ml} / \mathrm{kg}$, i.p.) or D. alfa $(25 \mu \mathrm{g} / \mathrm{kg}$, i.p. $)$. During the sample phase when animals were exposed to the test objects for the first time, STOP null mice and WT littermates that received either vehicle or D. alfa spent the same amount of time exploring both objects (Figure 1a). In contrast, during the choice phase, STOP mice that received vehicle explored the novel object less than WT littermates, which were injected with vehicle (Figure $1 b ; p=0.0372$ ). Administration of D. alfa did not alter the proportion of time that WT littermates spent investigating the novel object during the choice phase (Figure 1b). In comparison with vehicleinjected STOP null mice, D. alfa-treated mice spent significantly more time exploring the novel object during the choice phase (Figure $1 \mathrm{~b} ; p=0.0204$ ).

\section{Effects of Acute Darbepoetin Alfa NADPH Staining in the Forebrain}

It has been reported that local delivery of Epo in the hippocampus increases extracellular concentrations of nitric oxide (Yamamoto et al, 2004) suggesting that Epo activates nitric oxide synthase (NOS). The NADPH-d histochemical technique is based on the presence in certain neurons of NOS that can catalyze the NADPH-dependent conversion of a soluble tetrazolium salt to an insoluble, visible formazan product (Hope et al, 1991). In a second series of studies, we compared the effects of vehicle and D. alfa on NADPH-d staining in the forebrain of WT mice. Relative to vehicle-treated animals, D. alfa produced an increase in NADPH-d staining in the ventral CA1
(Figure 2c and d; arrowheads) and amygdala (medial and cortical aspects) (Figure $2 \mathrm{e}$ and $\mathrm{f}$; arrowheads). Image analysis indicated that the intensity of NADPH-d staining (NADPH-d index) in the ventral CA1 was elevated $3 \mathrm{~h}$ after D. alfa $(25 \mu \mathrm{g} / \mathrm{kg}$, i.p.) by $30 \%$ relative to vehicle $(10 \mathrm{ml} / \mathrm{kg}$, i.p.) treated controls $(p=0.0091)$. The NADPH-d index in the medial and cortical aspects of the amygdala was elevated by about $20 \%$ in mice that received D. alfa $(25 \mu \mathrm{g} / \mathrm{kg}$, i.p. $)$ compared with vehicle $(10 \mathrm{ml} / \mathrm{kg}$, i.p.) controls (Figure $2 \mathrm{~g}$; $p=0.0260)$; however, there was not a corresponding increase in NADPH-d staining intensity in dorsal CA1, whole cortex and rhinal cortex (Figure $2 \mathrm{~g}$ ).

\section{Effects of Acute Darbepoetin Alfa Treatment on Nitrate/ Nitrite Levels in the Hippocampus and Cortex}

NADPH-d staining suggested a single injection of D. alfa increased NOS activity in the ventral hippocampus but not the rhinal cortex (Figure $2 \mathrm{~g}$ ). NO, which is produced by activation of NOS, is an unstable molecule that degrades within seconds once formed, however, its end-products (nitrate and nitrite, NOx) are stable products and reflect NO concentrations in vivo (Moncada et al, 1991). In a third series of studies, we compared the effects of vehicle and D. alfa on NOx levels 3-4 h later in the hippocampus and cortex of STOP null and WT littermates. As shown in Figure $3 \mathrm{~b}$, basal NOx levels in hippocampus were comparable in WT and STOP null mice and elevated by more than $70 \%$ following D. alfa $(25 \mu \mathrm{g} / \mathrm{kg}$, i.p. $)$ in both strains (Figure 3b; WT: $p=0.0205$, KO: $p=0.0007$ ). In contrast, NOx levels in whole cortex were the same in WT and STOP null mice after D. alfa treatment (Figure 3a).

\section{L-NAME Inhibits the Increase in NOx Levels Produced by D. alfa}

The results shown in Figures 2 and 3 suggest that D. alfa may increase the NOx levels by activating NOS in the mouse hippocampus. In a fourth series of experiments, we tested this hypothesis by determining whether L-NAME, a potent NOS inhibitor, prevented the increase of NOx induced by D. alfa $(25 \mu \mathrm{g} / \mathrm{kg}$, i.p. $)$ in WT mice. We administered L-NAME at doses of 10,25 , or $50 \mathrm{mg} / \mathrm{kg}$ (i.p.) $30 \mathrm{~min}$ before D. alfa $(25 \mu \mathrm{g} / \mathrm{kg}$, i.p.) treatment, and then measured the concentration of NOx in the hippocampus 3-4h later. As shown in Figure $4 \mathrm{a}, \mathrm{D}$. alfa $(25 \mu \mathrm{g} / \mathrm{kg}$, i.p.) increased $\mathrm{NOx}$ levels in the hippocampus of WT mice by about $70 \%$ relative to vehicle-injected controls (Figure $4 \mathrm{a} ; p=0.0454$ ). D. alfa-induced increases in NOx levels were reversed by 25 or $50 \mathrm{mg} / \mathrm{kg}$ of L-NAME (Figure $4 \mathrm{a} ; 25 \mathrm{mg} / \mathrm{kg}$ : $p=0.0116$; $50 \mathrm{mg} / \mathrm{kg}: p=0.0151)$.

\section{Effects of L-NAME on NORT Performance}

In a fifth experiment, we determined the effects of L-NAME $(10,25$, and $50 \mathrm{mg} / \mathrm{kg}$, i.p.) on the NORT performance of WT mice. Compared with vehicle-injected mice, L-NAME did not reduce the amount of time that WT mice spent exploring the two test objects during the sample phase (Figure 4b). NORT performance during the choice phase was also not reduced by L-NAME $(10,25$, and $50 \mathrm{mg} / \mathrm{kg}$, i.p.) relative to vehicle-injected controls 
a

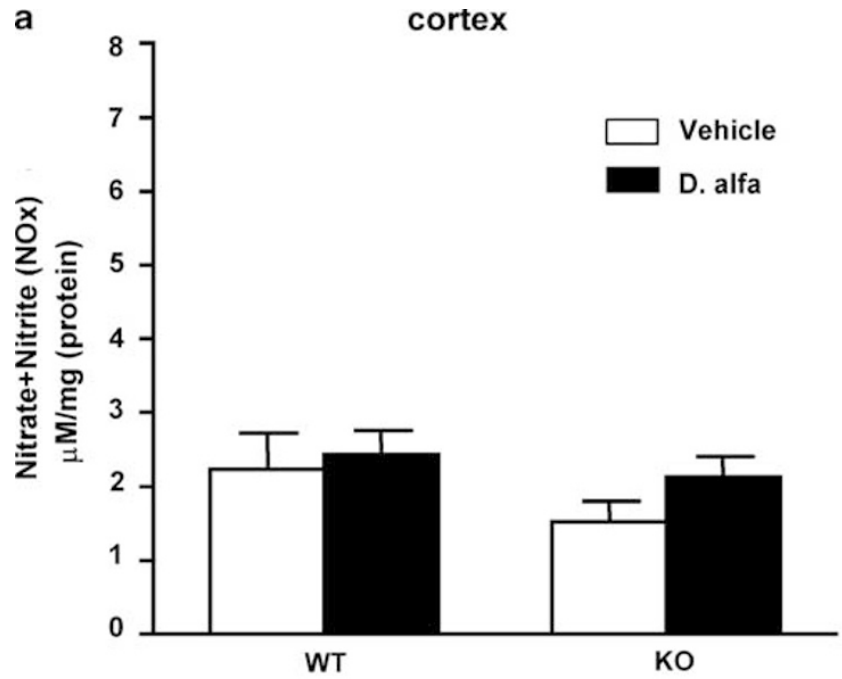

b

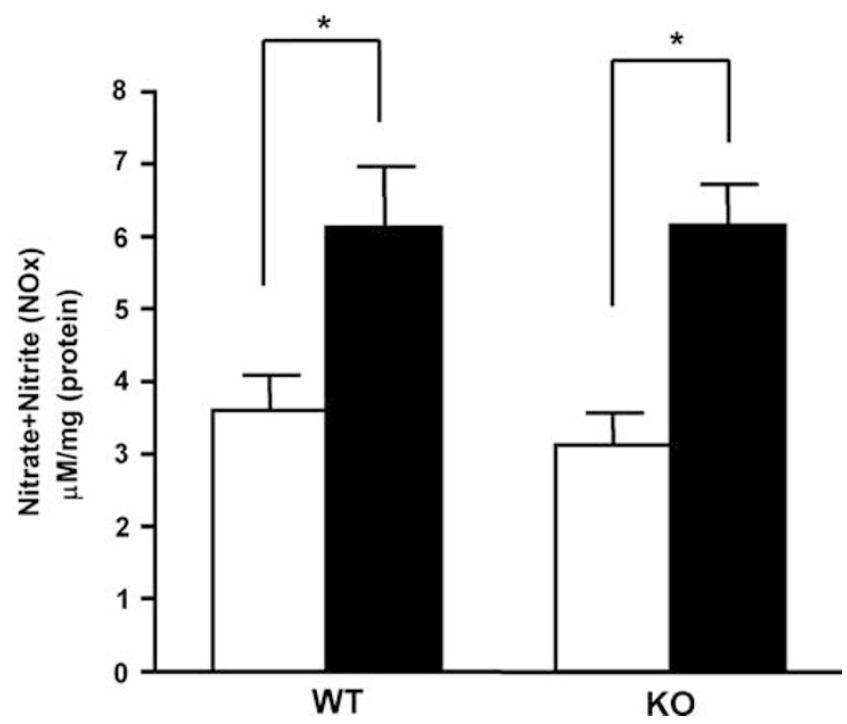

Figure 3 Nitrate and nitrite (NOx) levels in brain tissue from wild-type (WT) and STOP null mice (KO) that received either D. alfa $(25 \mu \mathrm{g} / \mathrm{kg}$, i.p.) or vehicle $(10 \mathrm{ml} / \mathrm{kg}$, i.p.). (a) NOx levels in cortex. (b) NOx levels in hippocampus. NOx levels $[\mu \mathrm{M} / \mathrm{mg}$ (protein)] are shown in the bar graph as mean \pm SEM. NOx levels in hippocampus were increased in both WT and $\mathrm{KO}$ mice 3-4 h after D. alfa treatment. White bars, vehicle $(10 \mathrm{ml} / \mathrm{kg}$; WT: $N=8, K O: N=8)$; black bars, D. alfa $(25 \mu \mathrm{g} / \mathrm{kg}$ i.p.; $\mathrm{WT}: N=10, \mathrm{KO}$ : $N=8)$. Two-way ANOVA with Bonferroni post hoc $t$-test, $* p<0.05$.

(Figure 4c). These results indicate that a dose of $25 \mathrm{mg} / \mathrm{kg}$ (i.p.) of L-NAME did not impair the basal NORT performance of WT mice, but sufficient to completely inhibit the increase in hippocampal NOx levels produced by D. alfa $(25 \mathrm{mg} / \mathrm{kg}$, i.p. $)$.

\section{L-NAME Inhibits the Ability of D. alfa to Improve the NORT Performance of STOP Null Mice}

Since NO has a role in synaptic connectivity (Boehning and Snyder, 2003; Ota et al, 2008; Wang et al, 2005), we hypothesized that $\mathrm{D}$. alfa may improve NORT performance in STOP null mice by increasing NO level in hippocampus.
To test this hypothesis, we performed a sixth experiment to determine if administration of L-NAME (25 mg/kg, i.p.) blocked the ability of D. alfa $(25 \mu \mathrm{g} / \mathrm{kg}$, i.p.) to improve NORT performance. L-NAME $(25 \mathrm{mg} / \mathrm{kg}$, i.p.) administration did not influence the exploration times of WT and STOP mice injected with vehicle $(10 \mathrm{ml} / \mathrm{kg}$, i.p.) or D. alfa $(25 \mu \mathrm{g} / \mathrm{kg}$, i.p.) during the sample phase (Figure 5a). The ability of D. alfa $(25 \mu \mathrm{g} / \mathrm{kg}$, i.p.) to improve the performance of STOP null mice in the choice phase (Figure $1 \mathrm{~b}$ ) was blocked by L-NAME ( $25 \mathrm{mg} / \mathrm{kg}$, i.p.) (Figure $5 \mathrm{~b}$; vehicle $v s \mathrm{D}$. alfa in WT $p=0.0366$, vehicle $v s$ D.alfa in KO $p=0.0074$ ). L-NAME $(25 \mathrm{mg} / \mathrm{kg}$, i.p.) did not alter the NORT performance of WT mice that received vehicle $(10 \mathrm{ml} / \mathrm{kg}$, i.p.) (Figure 5b).

\section{L-NAME Inhibits the Ability of D. alfa to Elevate NOx Levels in the Hippocampus}

Finally, NOx levels were measured in the hippocampus to confirm that L-NAME $(25 \mathrm{mg} / \mathrm{kg}$, i.p.) blocked the increase in NOS activity triggered by D. alfa $(25 \mu \mathrm{g} / \mathrm{kg}$, i.p.). D. alfa $(25 \mu \mathrm{g} / \mathrm{kg}$, i.p.) produced more than a $70 \%$ increase in $\mathrm{NOx}$ levels in both WT and STOP null mice (Figure $3 \mathrm{~b}$ ). Injection of L-NAME (25 mg/kg, i.p.) $30 \mathrm{~min}$ before D. alfa $(25 \mu \mathrm{g} / \mathrm{kg}$, i.p.) completely blocked the ability of D. alfa to increase in NOx levels in both WT and STOP null indicating that NOS activity was blocked by systemic administration of this inhibitor (Figure 5c). Taken together, these results indicate that D. alfa improved the NORT performance of STOP null mice by increasing NO level in the hippocampus.

\section{DISCUSSION}

A major finding of this study was that acute injection of D. alfa $(25 \mu \mathrm{g} / \mathrm{kg}$, i.p. $)$ reversed NORT performance deficits of STOP null mice that model several features of schizophrenia. There are several reports in the literature indicating that Epo is able to enhance cognitive function in rodents. For example, recombinant human Epo enhances the performance of healthy mice in behavioral tasks designed to assess attention and executive function (Ehrenreich et al, 2004; El-Kordi et al, 2009). Furthermore, we have previously reported that $\mathrm{D}$. alfa improves the NORT performance of adult rats that have sustained lesions in the ventral hippocampus as neonates (postnatal day 7) or young adults (42 days of age) (Hori et al, 2007). This finding is consistent with a recent report that Epo enhances hippocampal LTP and learning in mice (Adamcio et al, 2008). Although D. alfa improved the NORT performance of STOP null mice, it did not enhance the performance of WT mice. This may have been due to a ceiling effect. For example, the NORT performance of WT mice may already be at an optimal level precluding any further improvements by D. alfa. However, this contrasts with a previous study showing that Epo vs placebo administration to well-functioning healthy volunteers was able to improve their neurocognitive function (Miskowiak et al, 2008a, b).

A second major finding of this study was that systemic administration of D. alfa elevated NOx levels in the brain. NO was originally identified as endothelium-derived relaxing factor (Furchgott and Vanhoutte, 1989) and since this 

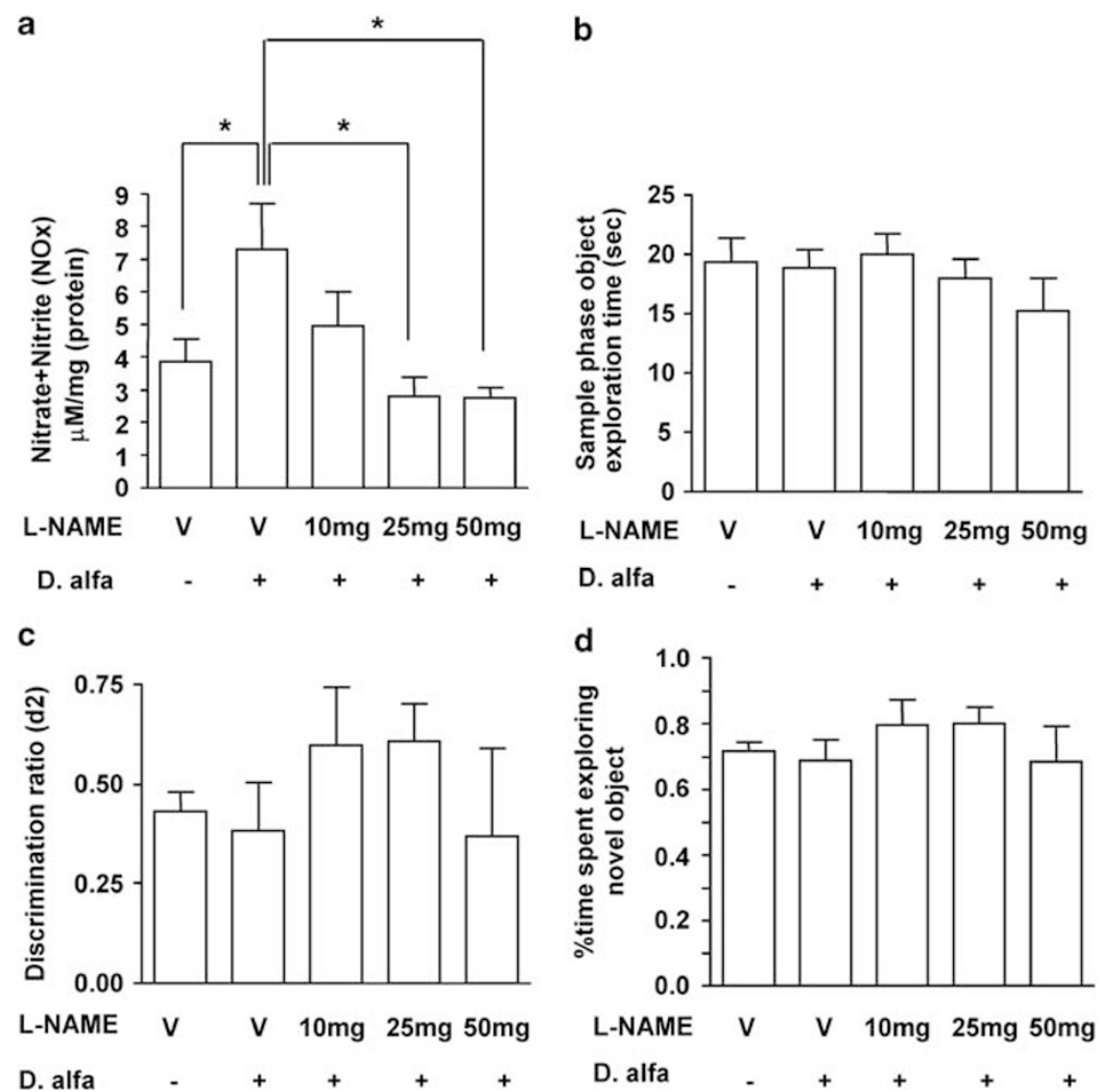

Figure 4 Effect of L-NAME on NOx levels and NORT performance in WT mice. L-NAME (I0, 25, or $50 \mathrm{mg} / \mathrm{kg}$; i.p.) was administered $30 \mathrm{~min}$ before vehicle $(10 \mathrm{ml} / \mathrm{kg}$, i.p.) or D. alfa $(25 \mu \mathrm{g} / \mathrm{kg}$ i.p.). NORT was performed $3 \mathrm{~h}$ after D. alfa treatment, and then hippocampi were subjected to measurement of NOx levels. (a) Dose-dependent inhibition of D. alfa $(25 \mu \mathrm{g} / \mathrm{kg}$, i.p.)-induced increases in nitrate and nitrite (NOx) levels in the hippocampus of wild-type mice by L-NAME. NOx levels $(\mu \mathrm{M} / \mathrm{mg}$ (protein)) are shown in the bar graph as mean \pm SEM. V; vehicle ( $10 \mathrm{ml} / \mathrm{kg}$, i.p.); Darbepoetin alfa, D. alfa ( $25 \mu \mathrm{g} / \mathrm{kg}$, i.p.), $V /-: N=5, V /+: N=6,10 \mathrm{mg} /+: N=5,25 \mathrm{mg} /+: N=6,50 \mathrm{mg} /+: N=5$. One-way ANOVA with Newman-Keuls test, $* 2<0.05$. (b) Object exploration time in the sample phase. Each bar represents the mean \pm SEM. Animals that received vehicle or L-NAME spent equivalent amounts of time exploring objects during sample phase. (c) Discrimination ratio (d2) during the choice phase for animals injected with vehicle (I0 ml/kg, i.p.) or L-NAME ( I0, 25, or $50 \mathrm{mg} / \mathrm{kg}$; i.p.). Each bar graph represents the mean \pm SEM. There were no significant differences between groups that received vehicle ( $10 \mathrm{ml} / \mathrm{kg}$, i.p.) or L-NAME (I0, 25, or $50 \mathrm{mg} / \mathrm{kg}$; i.p.), one-way ANOVA. (d) Percent time spent exploring the novel object during the choice phase. Each bar graph represents the mean \pm SEM. V; vehicle ( $10 \mathrm{ml} / \mathrm{kg})$; Darbepoetin alfa, D. alfa $(25 \mu \mathrm{g} / \mathrm{kg}), \mathrm{V} /-: \mathrm{N}=5, \mathrm{~V} /+: \mathrm{N}=6,10 \mathrm{mg} /+: \mathrm{N}=5,25 \mathrm{mg} /+: \mathrm{N}=6,50 \mathrm{mg} /+$ : $N=5$. There were no statistically significant differences among the groups, one-way ANOVA.

seminal observation has been implicated a wide variety of physiological processes underlying learning and memory (Kendrick et al, 1997; Ota et al, 2008). NO can signal across the synapse in both the antero- and retrograde directions to increase levels of the intracellular second messenger cyclic guanosine- $3^{\prime}, 5^{\prime}$-monophosphate (cGMP). It has been shown that cGMP activates cGMP-dependent protein kinases implicated in long-term potentiation (Feil and Kleppisch, 2008). Measurement of the nitrate and nitrite metabolites of NO (NOx) has shown that Epo can increase tissue levels of NO in both the peripheral and central nervous system. Transgenic mice that overexpress human Epo show a 3-fold increase in serum levels of NOx (Ruschitzka et al, 2000). In addition, Yamamoto et al, (2004) have reported that local delivery of Epo in the rat hippocampus induces more than a 2 -fold increase in extracellular levels of NOx (Yamamoto et al, 2004). Cherian et al, (2007) have found that systemic administration of Epo (5000 U/kg, s.c.; once a day for 3 days before injury) prevents the reduction in extracellular NO concentrations in the brain that occurs after cortical impact injury. In this study, we have shown that NOx levels are elevated in the hippocampus by 1.7 to 2 -fold in both WT and STOP null mice 3-4 h after injection of D. alfa $(25 \mu \mathrm{g} / \mathrm{kg}=5000 \mathrm{U} / \mathrm{kg}$, i.p.) (Figure 3).

In the central nervous system, NO has an important role as an intracellular chemical messenger (Boehning and Snyder, 2003; Dawson and Snyder, 1994; Kiss and Vizi, 2001). There are several reports that NO enhances the release of neurotransmitters implicated in cognitive performance such as acetylcholine and glutamate (Prast and Philippu, 1992, 2001). NO has also been shown to enhance the expression of synaptophysin and GluR1 necessary for synaptic connectivity (Wang et al, 2005). Moreover, it is well-established that NOS inhibitors block LTP (Arancio et al, 1996; Schuman and Madison, 1991), whereas LTP is significantly reduced in mice that lack both endothelial NOS and neuronal NOS (Son et al, 1996). Consistent with the importance of NO for learning and memory, we found that the ability of D. alfa to improve the NORT performance of STOP null mice was associated with elevated NO levels 
in the hippocampus. Furthermore, L-NAME, an inhibitor of both endothelial NOS and neuronal NOS, attenuated the improvement of NORT performance by D. alfa in STOP null mice, suggesting that NO may mediate the cognitive improvement induced by D. alfa (Figure 5). We did not observe impaired NORT performance in WT mice

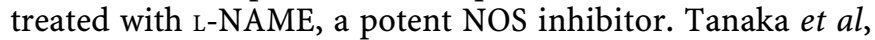
(2009) reported that a high dose of L-NAME $(100 \mathrm{mg} / \mathrm{kg}$, i.p.) impaired Y-maze task of mice, whereas lower doses of

a
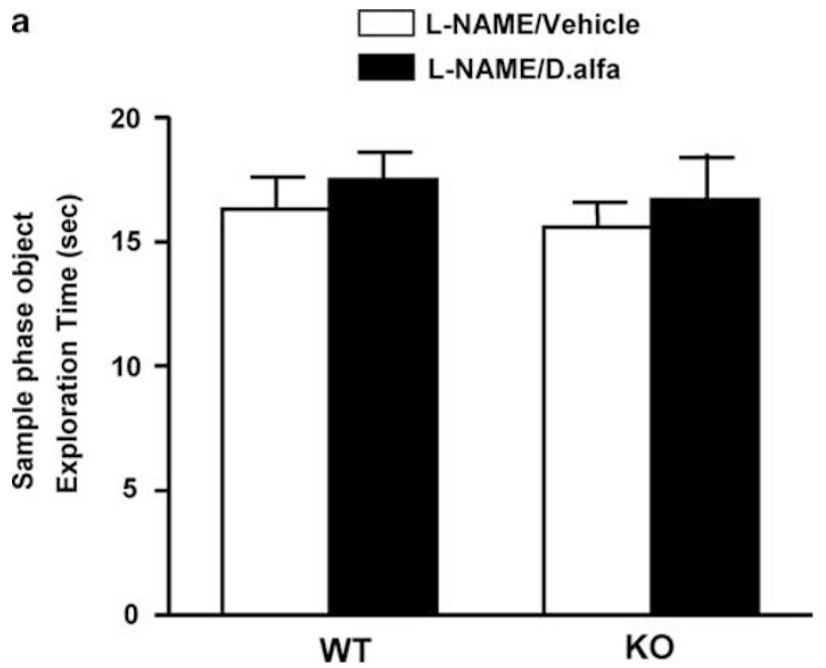

b

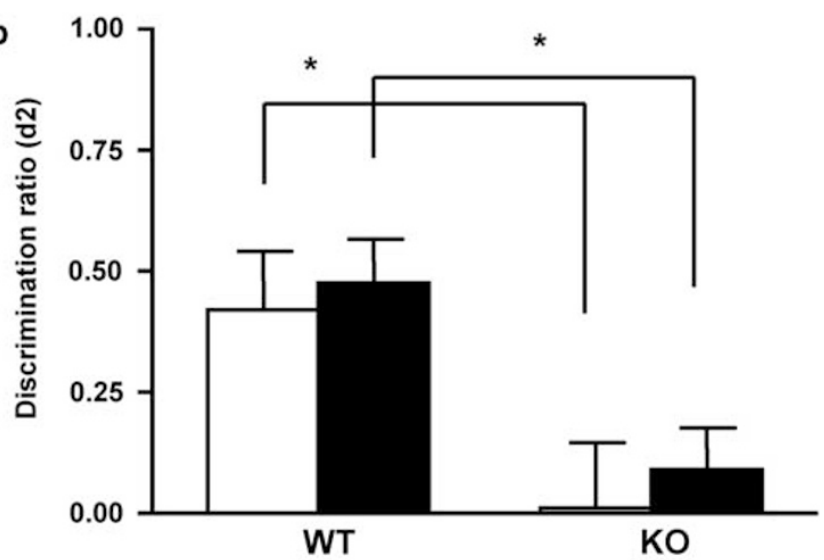

c

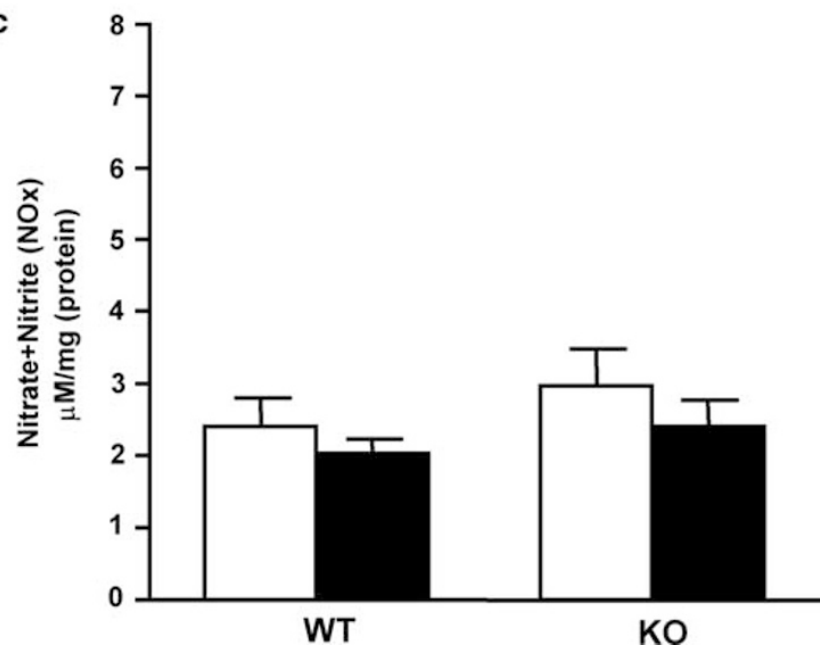

10,30 , and $50 \mathrm{mg} / \mathrm{kg}$ (i.p.) did not alter performance in this task. It therefore appears that the failure of L-NAME $(10-50 \mathrm{mg} / \mathrm{kg}$, i.p.) to inhibit the NORT performance of WT mice in this study was simply dose related.

It is noteworthy that serum levels of NO have been reported to be reduced in schizophrenic patients (Lee and Kim, 2008; Srivastava et al, 2001). Akbarian et al, (1993a, b) have found that some schizophrenic patients show a significant decline in NADPH-d-positive neurons in the dorsolateral prefrontal cortex, hippocampal formation, and lateral temporal lobe of the neocortex relative to controls matched for gender, age and post-mortem delay. These findings imply that decreased NO signaling in certain parts of the brain may contribute to cognitive dysfunction in schizophrenia. D. alfa increased NADPH-d staining intensity in the CA1 subregion of the ventral hippocampus suggesting that it may activate regions associated with cognitive function. These results raise the possibility that Epo might compensate for attenuated NO signaling in schizophrenia by enhancing NO production in the CA1 region. Ehrenreich et al, (2007) found that chronic schizophrenic patients receiving recombinant human Epo (40000 U per week for 12 weeks) displayed a significant improvement in cognitive deficits. Miskowiak et al, (2009) found that a single injection of erythropoietin $(40000 \mathrm{U})$ not only improved memory in depressed patients, but also enhanced mood and cognitive function in healthy volunteers (Miskowiak et al, 2008a,b). The ability of Epo to improve mood and cognitive function was also associated with an enhanced functional magnetic resonance imaging response in the hippocampus and amygdala (Miskowiak et al, 2007, 2008b). In support of these findings, we found that D. alfa enhanced NADPH-d staining intensity in the ventral hippocampus and amygdala (Figure 2).

Figure 5 L-NAME inhibits the improvement in NORT performance and the increase of NOx levels of STOP null mice that received $D$. alfa. Wild-type (WT) or STOP null mice (KO) were treated with L-NAME (25 mg/kg, i.p.) and vehicle ( $10 \mathrm{mg} / \mathrm{kg}$, i.p.; $W T: N=8, K O: N=8)$ or L-NAME ( $25 \mathrm{mg} / \mathrm{kg}$, i.p.) and D. alfa $(25 \mu g / \mathrm{kg}$, i.p.; $W T: N=9, K O: N=8)$. The first injection occurred $30 \mathrm{~min}$ before the second. NORT was performed $3 \mathrm{~h}$ after $\mathrm{D}$. alfa treatment, and then hippocampi were subjected to measurement of $\mathrm{NO}$ x levels. (a) Object exploration time in sample phase for WT and KO treated with L-NAME $(25 \mathrm{mg} / \mathrm{kg}$, i.p. $)$ and vehicle ( $10 \mathrm{mg} / \mathrm{kg}$, i.p.) or L-NAME ( $25 \mathrm{mg} / \mathrm{kg}$, i.p.) and D. alfa ( $25 \mu \mathrm{g} / \mathrm{kg}$, i.p.). Each bar represents mean \pm SEM. All four groups spent an equivalent amount of time investigating the objects during the sample phase. (b) Discrimination ratio (d2) in choice phase for WT or KO treated with L-NAME $(25 \mathrm{mg} / \mathrm{kg}$, i.p.) and vehicle $(10 \mathrm{mg} / \mathrm{kg}$, i.p.) or L-NAME $(25 \mathrm{mg} / \mathrm{kg}$, i.p.) and D. alfa $(25 \mu \mathrm{g} / \mathrm{kg}$, i.p.). Each bar represents mean \pm SEM. L-NAME $(25 \mathrm{mg} / \mathrm{kg}$, i.p.) blocked the ability of D. alfa ( $25 \mu \mathrm{g} / \mathrm{kg}$, i.p.) to improve NORT performance of KO. White bars, L-NAME $(25 \mathrm{mg} / \mathrm{kg})$ and vehicle $(10 \mathrm{ml} / \mathrm{kg})$; black bars, L-NAME $(25 \mathrm{mg} / \mathrm{kg})$ and D.alfa $(25 \mu \mathrm{g} / \mathrm{kg})$. Two-way ANOVA with Bonferroni post hoc t-test, $* p<0.05$. (c) L-NAME inhibited the increase in nitrate and nitrite (NOx) levels induced by $\mathrm{D}$. alfa in the hippocampus of wild-type and STOP null mice. The hippocampi from all animals were immediately removed and NOx measurements performed. NOx levels $(\mu \mathrm{M} / \mathrm{mg}$ (protein)) are shown in the bar graph as mean \pm SEM. L-NAME ( $25 \mathrm{mg} / \mathrm{kg}$, i.p.) blocked the ability of D. alfa ( $25 \mu \mathrm{g} / \mathrm{kg}$, i.p.) to increase NOx levels in both WT and KO mice. White bars, L-NAME $(25 \mathrm{mg} / \mathrm{kg}$, i.p.) and vehicle ( $10 \mathrm{ml} / \mathrm{kg}$, i.p.); black bars, L-NAME $(25 \mathrm{mg} / \mathrm{kg}$, i.p.) and D.alfa $(25 \mu \mathrm{g} / \mathrm{kg}$, i.p.). There were no statistically significant differences among the groups, two-way ANOVA. 
Although Epo appears to enhance cognitive function in psychiatric illness, it can also have serious adverse effects. For example, chronic Epo treatment significantly increases the risk of thrombosis (Singbartl, 1994). Furthermore, many malignant tumors express both Epo and Epo receptor, and Epo-sensitive tumor growth is supported by Epo both in vitro and in vivo (Yasuda et al, 2003). Unfortunately, Ehrenreich et al, (2007) reported that chronic administration of Epo (40000 U per week for 12 weeks) significantly increased hematocrit and that it was necessary to perform bloodletting on several subjects. In what may be a resolution of this problem, Miskowiak and coworkers reported that a single injection of Epo $(40000 \mathrm{U})$ did not increase hematocrit within 3 or 7 days in their studies (Miskowiak et al, 2007, 2008a, b, 2009) suggesting that it may be possible to improve cognition at doses that do not raise hematocrit at least 7 days after a single administration of this therapeutic. In this study, we did not determine the duration for which a single injection of D. alfa $(25 \mu \mathrm{g} / \mathrm{kg}$, i.p.) improved the NORT performance of STOP null mice. In view of the findings by Miskowiak and coworkers, it would be useful to determine the duration of the effects of D. alfa on the NORT performance of STOP null mice.

In summary, we show that a single injection of $\mathrm{D}$. alfa $(25 \mu \mathrm{g} / \mathrm{kg}$, i.p.) improved the behavioral performance of STOP null mice in the NORT. This improvement was associated with an elevation of tissue levels of NOx in regions of the brain implicated in NORT performance. Furthermore, inhibition of NOS by injection of the inhibitor L-NAME, at a dose that did not impair the basal NORT performance of WT mice, blocked the ability of D. alfa to enhance the NORT performance of STOP null mice. These findings suggest that erythropoietin may improve the cognitive performance of schizophrenics by enhancing NO signaling in regions of the brain associated with learning and memory.

\section{ACKNOWLEDGEMENTS}

KK was supported by Reynolds Postdoctoral Award and Sobey Postdoctoral Fellowship in Psychiatry Research. We thank Elizabeth Belland, Julie Dauphinee, Yanli Zhou and Kay Murphy for excellent technical assistance. We thank Annie Andrieux for generously providing a breeding trio of STOP null mice used to establish a colony at our university. This work was supported by a research grant from the Department of Psychiatry Research Fund at Dalhousie University.

\section{DISCLOSURE}

The authors declare no conflict of interest.

\section{REFERENCES}

Adamcio B, Sargin D, Stradomska A, Medrihan L, Gertler C, Theis $\mathrm{F}$ et al (2008). Erythropoietin enhances hippocampal longterm potentiation and memory. BMC Biol 6: 37.

Adembri C, Bechi A, Meli E, Gramigni E, Venturi L, Moroni F et al (2004). Erythropoietin attenuates post-traumatic injury in organotypic hippocampal slices. J Neurotrauma 21: 1103-1112.
Akbarian S, Bunney Jr WE, Potkin SG, Wigal SB, Hagman JO, Sandman CA et al (1993a). Altered distribution of nicotinamideadenine dinucleotide phosphate-diaphorase cells in frontal lobe of schizophrenics implies disturbances of cortical development. Arch Gen Psychiatry 50: 169-177.

Akbarian S, Vinuela A, Kim JJ, Potkin SG, Bunney Jr WE, Jones EG (1993b). Distorted distribution of nicotinamide-adenine dinucleotide phosphate-diaphorase neurons in temporal lobe of schizophrenics implies anomalous cortical development. Arch Gen Psychiatry 50: 178-187.

Andreasen NC, Flaum M (1991). Schizophrenia: the characteristic symptoms. Schizophr Bull 17: 27-49.

Andrieux A, Salin PA, Vernet M, Kujala P, Baratier J, Gory-Faure S et al (2002). The suppression of brain cold-stable microtubules in mice induces synaptic defects associated with neurolepticsensitive behavioral disorders. Genes Dev 16: 2350-2364.

Arancio O, Kiebler M, Lee CJ, Lev-Ram V, Tsien RY, Kandel ER et al (1996). Nitric oxide acts directly in the presynaptic neuron to produce long-term potentiation in cultured hippocampal neurons. Cell 87: 1025-1035.

Ayhan Y, Abazyan B, Nomura J, Kim R, Ladenheim B, Krasnova IN et al Differential effects of prenatal and postnatal expressions of mutant human DISC1 on neurobehavioral phenotypes in transgenic mice: evidence for neurodevelopmental origin of major psychiatric disorders. Mol Psychiatry. (originally published online Jan. 5, 2010, at www.nature.com/mp/journal/ vaop/ncurrent/abs/mp2009144a.html).

Begou M, Volle J, Bertrand JB, Brun P, Job D, Schweitzer A et al (2008). The stop null mice model for schizophrenia displays [corrected] cognitive and social deficits partly alleviated by neuroleptics. Neuroscience 157: 29-39.

Boehning D, Snyder SH (2003). Novel neural modulators. Annu Rev Neurosci 26: 105-131.

Bosc C, Andrieux A, Job D (2003). STOP proteins. Biochemistry 42: 12125-12132.

Bouvrais-Veret C, Weiss S, Hanoun N, Andrieux A, Schweitzer A, Job D et al (2008). Microtubule-associated STOP protein deletion triggers restricted changes in dopaminergic neurotransmission. J Neurochem 104: 745-756.

Breier A (2005). Developing drugs for cognitive impairment in schizophrenia. Schizophr Bull 31: 816-822.

Brenner E, Sonnewald U, Schweitzer A, Andrieux A, Nehlig A (2007). Hypoglutamatergic activity in the STOP knockout mouse: a potential model for chronic untreated schizophrenia. J Neurosci Res 85: 3487-3493.

Brines ML, Ghezzi P, Keenan S, Agnello D, de Lanerolle NC, Cerami C et al (2000). Erythropoietin crosses the blood-brain barrier to protect against experimental brain injury. Proc Natl Acad Sci USA 97: 10526-10531.

Broadbent NJ, Squire LR, Clark RE (2004). Spatial memory, recognition memory, and the hippocampus. Proc Natl Acad Sci USA 101: 14515-14520.

Brun P, Begou M, Andrieux A, Mouly-Badina L, Clerget M, Schweitzer A et al (2005). Dopaminergic transmission in STOP null mice. J Neurochem 94: 63-73.

Callicott JH, Straub RE, Pezawas L, Egan MF, Mattay VS, Hariri AR et al (2005). Variation in DISC1 affects hippocampal structure and function and increases risk for schizophrenia. Proc Natl Acad Sci USA 102: 8627-8632.

Carlsson A, Waters N, Waters S, Carlsson ML (2000). Network interactions in schizophrenia-therapeutic implications. Brain Res Brain Res Rev 31: 342-349.

Cherian L, Goodman JC, Robertson C (2007). Neuroprotection with erythropoietin administration following controlled cortical impact injury in rats. J Pharmacol Exp Ther 322: 789-794.

Dawson TM, Snyder SH (1994). Gases as biological messengers: nitric oxide and carbon monoxide in the brain. J Neurosci 14: 5147-5159. 
Delotterie D, Ruiz G, Brocard J, Schweitzer A, Roucard C, Roche Y et al (2010). Chronic administration of atypical antipsychotics improves behavioral and synaptic defects of STOP null mice. Psychopharmacology (Berlin) 208: 131-141.

Denarier E, Aguezzoul M, Jolly C, Vourc'h C, Roure A, Andrieux A et al (1998). Genomic structure and chromosomal mapping of the mouse STOP gene (Mtap6). Biochem Biophys Res Commun 243: 791-796.

Eastwood SL, Lyon L, George L, Andrieux A, Job D, Harrison PJ (2007). Altered expression of synaptic protein mRNAs in STOP (MAP6) mutant mice. J Psychopharmacol 21: 635-644.

Ehrenreich H, Degner D, Meller J, Brines M, Behe M, Hasselblatt M et al (2004). Erythropoietin: a candidate compound for neuroprotection in schizophrenia. Mol Psychiatry 9: 42-54.

Ehrenreich H, Hinze-Selch D, Stawicki S, Aust C, Knolle-Veentjer S, Wilms $S$ et al (2007). Improvement of cognitive functions in chronic schizophrenic patients by recombinant human erythropoietin. Mol Psychiatry 12: 206-220.

El-Kordi A, Radyushkin K, Ehrenreich H (2009). Erythropoietin improves operant conditioning and stability of cognitive performance in mice. BMC Biol 7: 37.

Feil R, Kleppisch T (2008). NO/cGMP-dependent modulation of synaptic transmission. Handb Exp Pharmacol 184: 529-560.

Fradley RL, O'Meara GF, Newman RJ, Andrieux A, Job D, Reynolds DS (2005). STOP knockout and NMDA NR1 hypomorphic mice exhibit deficits in sensorimotor gating. Behav Brain Res 163: 257-264.

Furchgott RF, Vanhoutte PM (1989). Endothelium-derived relaxing and contracting factors. FASEB $J$ 3: 2007-2018.

Galiano MR, Bosc C, Schweitzer A, Andrieux A, Job D, Hallak ME (2004). Astrocytes and oligodendrocytes express different STOP protein isoforms. J Neurosci Res 78: 329-337.

Ghezzi P, Brines M (2004). Erythropoietin as an antiapoptotic, tissue-protective cytokine. Cell Death Differ 11(Suppl 1): S37-S44.

Harrison PJ (1999). The neuropathology of schizophrenia. A critical review of the data and their interpretation. Brain 122(Part 4): 593-624.

Hope BT, Michael GJ, Knigge KM, Vincent SR (1991). Neuronal NADPH diaphorase is a nitric oxide synthase. Proc Natl Acad Sci USA 88: 2811-2814.

Hope BT, Vincent SR (1989). Histochemical characterization of neuronal NADPH-diaphorase. J Histochem Cytochem 37: 653-661.

Hori SE, Powell KJ, Robertson GS (2007). Darbepoetin alfa (Aranesp) improves recognition memory in adult rats that have sustained bilateral ventral hippocampal lesions as neonates or young adults. Neuroscience 144: 1-7.

Jablensky A (2004). Resolving schizophrenia's CATCH22. Nat Genet 36: 674-675.

Keefe RS, Fenton WS (2007). How should DSM-V criteria for schizophrenia include cognitive impairment? Schizophr Bull 33: 912-920.

Kendrick KM, Guevara-Guzman R, Zorrilla J, Hinton MR, Broad KD, Mimmack M et al (1997). Formation of olfactory memories mediated by nitric oxide. Nature 388: 670-674.

Kiss JP, Vizi ES (2001). Nitric oxide: a novel link between synaptic and nonsynaptic transmission. Trends Neurosci 24: 211-215.

Lee BH, Kim YK (2008). Reduced plasma nitric oxide metabolites before and after antipsychotic treatment in patients with schizophrenia compared to controls. Schizophr Res 104: 36-43.

Li W, Maeda Y, Yuan RR, Elkabes S, Cook S, Dowling P (2004). Beneficial effect of erythropoietin on experimental allergic encephalomyelitis. Ann Neurol 56: 767-777.

Mirnics K, Middleton FA, Marquez A, Lewis DA, Levitt P (2000). Molecular characterization of schizophrenia viewed by microarray analysis of gene expression in prefrontal cortex. Neuron 28: 53-67.
Miskowiak K, Inkster B, O'Sullivan U, Selvaraj S, Goodwin GM, Harmer CJ (2008a). Differential effects of erythropoietin on neural and cognitive measures of executive function 3 and 7 days post-administration. Exp Brain Res 184: 313-321.

Miskowiak K, Inkster B, Selvaraj S, Wise R, Goodwin GM, Harmer CJ (2008b). Erythropoietin improves mood and modulates the cognitive and neural processing of emotion 3 days post administration. Neuropsychopharmacology 33: 611-618.

Miskowiak K, O'Sullivan U, Harmer CJ (2007). Erythropoietin enhances hippocampal response during memory retrieval in humans. J Neurosci 27: 2788-2792.

Miskowiak KW, Favaron E, Hafizi S, Inkster B, Goodwin GM, Cowen PJ et al (2009). Effects of erythropoietin on emotional processing biases in patients with major depression: an exploratory fMRI study. Psychopharmacology (Berlin) 207: 133-142.

Moncada S, Palmer RM, Higgs EA (1991). Nitric oxide: physiology, pathophysiology, and pharmacology. Pharmacol Rev 43: 109-142.

Mueser KT, McGurk SR (2004). Schizophrenia. Lancet 363: 2063-2072.

Orhan B, Yalcin S, Nurlu G, Zeybek D, Muftuoglu S (2004). Erythropoietin against cisplatin-induced peripheral neurotoxicity in rats. Med Oncol 21: 197-203.

Ota KT, Pierre VJ, Ploski JE, Queen K, Schafe GE (2008). The NO-cGMP-PKG signaling pathway regulates synaptic plasticity and fear memory consolidation in the lateral amygdala via activation of ERK/MAP kinase. Learn Mem 15: 792-805.

Powell KJ, Hori SE, Leslie R, Andrieux A, Schellinck H, Thorne M et al (2007). Cognitive impairments in the STOP null mouse model of schizophrenia. Behav Neurosci 121: 826-835.

Prast H, Philippu A (1992). Nitric oxide releases acetylcholine in the basal forebrain. Eur J Pharmacol 216: 139-140.

Prast H, Philippu A (2001). Nitric oxide as modulator of neuronal function. Prog Neurobiol 64: 51-68.

Ranganath C, Minzenberg MJ, Ragland JD (2008). The cognitive neuroscience of memory function and dysfunction in schizophrenia. Biol Psychiatry 64: 18-25.

Robertson GS, Hori SE, Powell KJ (2006). Schizophrenia: an integrative approach to modelling a complex disorder. J Psychiatry Neurosci 31: 157-167.

Ruschitzka FT, Wenger RH, Stallmach T, Quaschning T, de Wit C, Wagner $\mathrm{K}$ et al (2000). Nitric oxide prevents cardiovascular disease and determines survival in polyglobulic mice overexpressing erythropoietin. Proc Natl Acad Sci USA 97: 11609-11613.

Sadamoto Y, Igase K, Sakanaka M, Sato K, Otsuka H, Sakaki S et al (1998). Erythropoietin prevents place navigation disability and cortical infarction in rats with permanent occlusion of the middle cerebral artery. Biochem Biophys Res Commun 253: 26-32.

Sakanaka M, Wen TC, Matsuda S, Masuda S, Morishita E, Nagao M et al (1998). In vivo evidence that erythropoietin protects neurons from ischemic damage. Proc Natl Acad Sci USA 95: 4635-4640.

Sawa A, Snyder SH (2002). Schizophrenia: diverse approaches to a complex disease. Science 296: 692-695.

Schuman EM, Madison DV (1991). A requirement for the intercellular messenger nitric oxide in long-term potentiation. Science 254: 1503-1506.

Shimizu H, Iwayama Y, Yamada K, Toyota T, Minabe Y, Nakamura $\mathrm{K}$ et al (2006). Genetic and expression analyses of the STOP (MAP6) gene in schizophrenia. Schizophr Res 84: 244-252.

Singbartl G (1994). Adverse events of erythropoietin in long-term and in acute/short-term treatment. Clin Investig 72(6 Suppl): S36-S43.

Son H, Hawkins RD, Martin K, Kiebler M, Huang PL, Fishman MC et al (1996). Long-term potentiation is reduced in mice that are 
doubly mutant in endothelial and neuronal nitric oxide synthase. Cell 87: 1015-1023.

Srivastava N, Barthwal MK, Dalal PK, Agarwal AK, Nag D, Srimal RC et al (2001). Nitrite content and antioxidant enzyme levels in the blood of schizophrenia patients. Psychopharmacology (Berlin) 158: 140-145.

Tanaka K, Yagi T, Shimakoshi R, Azuma K, Nanba T, Ogo H et al (2009). Effects of galantamine on L-NAME-induced behavioral impairment in Y-maze task in mice. Neurosci Lett 462: 235-238. van Os J, Kapur S (2009). Schizophrenia. Lancet 374: 635-645.

Vincent SR, Kimura H (1992). Histochemical mapping of nitric oxide synthase in the rat brain. Neuroscience 46: 755-784.

Wang HG, Lu FM, Jin I, Udo H, Kandel ER, de Vente J et al (2005). Presynaptic and postsynaptic roles of NO, cGK, and RhoA in long-lasting potentiation and aggregation of synaptic proteins. Neuron 45: 389-403.

Winters BD, Forwood SE, Cowell RA, Saksida LM, Bussey TJ (2004). Double dissociation between the effects of peri- postrhinal cortex and hippocampal lesions on tests of object recognition and spatial memory: heterogeneity of function within the temporal lobe. J Neurosci 24: 5901-5908.

Yamamoto M, Koshimura K, Sohmiya M, Murakami Y, Kato Y (2004). Effect of erythropoietin on nitric oxide production in the rat hippocampus using in vivo brain microdialysis. Neuroscience 128: $163-168$.

Yasuda Y, Fujita Y, Matsuo T, Koinuma S, Hara S, Tazaki A et al (2003). Erythropoietin regulates tumour growth of human malignancies. Carcinogenesis 24: 1021-1029.

Young JW, Powell SB, Risbrough V, Marston HM, Geyer MA (2009). Using the MATRICS to guide development of a preclinical cognitive test battery for research in schizophrenia. Pharmacol Ther 122: 150-202.

Zhang W, Sun B, Wang X, Liu J, Zhang Z, Geng S (2010). Erythropoietin enhances survival of facial motor neurons by inhibiting expression of inducible nitric oxide synthase after axotomy. J Clin Neurosci 17: 368-371. 